\title{
LA BRECHA DE MERCEDES VALDIVIESO, ENTRE CONTINUIDADES Y RUPTURAS
}

\author{
Natalia Cisterna \\ Universidad de Chile \\ Santiago, Chile \\ natacisterna@gmail.com
}

RESUMEN / ABSTRACT

\begin{abstract}
Este artículo se propone analizar La brecha (1961) de Mercedes Valdivieso en el marco de una tradición de representaciones del sujeto femenino y su mundo, presentes en narrativas de autoras latinoamericanas de la primera mitad del siglo XX. En la novela es posible identificar una serie de imágenes que fueron configurando las autoras en sus distintas ficciones y que contribuyeron a pensar y visibilizar las condiciones de sujeción de la mujer en la sociedad moderna. Asimismo, la novela se sitúa en esta genealogía aportando con nuevos enfoques ideológicos, renovando con ello el arco de representaciones femeninas de la literatura de mujeres. El análisis se centrará fundamentalmente en dos ejes: la imagen de la "otra" en cuanto encarnación de una identidad de género disidente y la relación del yo femenino con los espacios públicos y privados.
\end{abstract}

Palabras Clave: narrativas de mujeres, autoras latinoamericanas, representaciones del sujeto femenino, políticas de desposesión.

\section{MERCEDES VALDIVIESO'S LA BRECHA, BETWEEN CONTINUITIES AND RUPTURES}

This article analyzes La brecha (1961) by Mercedes Valdivieso within the framework of a tradition of representations of the female subject and her world, present in narratives by Latin American women authors of the first half of the twentieth century. It is possible to identify in this novel a series of images that were configured by different female authors in their fictions and that contributed to think about and make visible the conditions of subjection of women in modern society. Likewise, the novel is situated in this genealogy, contributing with new ideological approaches, thus renewing the arc of feminine representations in women's literature. 
The analysis will focus primarily on two axes: the image of the other as the embodiment of a dissident gender identity and the relationship of the female self to public and private spaces.

KEYWORDS: women's narratives, Latin American women writers, representations of the female subject, dispossession policies.

En uno de los pasajes de La brecha (1961), de Mercedes Valdivieso, su protagonista pierde la conciencia y se ve de pronto sumergida en una espesa niebla. En medio de la bruma blanca aparece la figura de Marta, su mejor amiga, quien la arranca de ese adormecimiento y la regresa a la vida (62-63). La protagonista se encuentra, por ese entonces, viviendo una difícil separación conyugal, que aunque la hace vislumbrar con entusiasmo un futuro nuevo, también la llena de incertidumbre. Resulta imposible no leer este pasaje sin advertir la referencia a la novela de María Luisa Bombal, La última niebla (1931). Escrita tres décadas antes, la historia de Bombal también nos describe a una protagonista que, si bien no tiene planes de separarse, vive una crisis matrimonial profunda que la lleva a experimentar su vida de casada como un estado de inexistencia, una anulación permanente de su individualidad. En la novela de Bombal, la niebla desdibuja las diferencias, homologa los espacios, paisajes y subjetividades, y envuelve todo en una suerte de rueda existencial sin variaciones. Así, la niebla como metáfora de una vida signada por la imposibilidad de la autodeterminación y, en definitiva, del cambio, se constituye en la imagen más representativa y categórica que nos ha ofrecido la literatura chilena de la sujeción de la mujer en una cultura patriarcal.

La decisión de Mercedes Valdivieso de escoger la niebla como figura central en el breve pasaje descrito no es casual. Como feminista y lectora dedicada, entiende los alcances de tal evocación. El diálogo intertextual en La brecha no solo es un homenaje a una obra pionera, como lo es La última niebla, sino sobre todo una decisión política. A través de esta imagen, la autora se reconoce en una tradición escritural de mujeres, que profundizó en la configuración de subjetividades y experiencias femeninas, inmersas en un sistema patriarcal asfixiante y envolvente. Asimismo, abre una nueva senda representacional. A diferencia de la protagonista de Bombal, la de Valdivieso logra dejar atrás la niebla gracias al auxilio de su amiga. Este es, sin duda, uno de los elementos más novedosos y rupturistas de la novela: 
pone en escena la sororidad femenina como un factor necesario para superar la condición de desposesión de la mujer y dar lugar a la constitución del yo.

En las páginas siguientes me interesa explorar, precisamente, cómo la novela se identifica en una historia representacional previa de escritura de mujeres y, al mismo tiempo, la modifica para así proponer nuevas posibilidades simbólicas y políticas de constitución del sujeto femenino. Para desarrollar esta reflexión, me centraré en ciertos ejes que, a mi modo de ver, permiten observar las continuidades y rupturas que despliega La brecha respecto a las narrativas predecesoras. Estos ejes son la constitución de la "otra" en relación a las protagonistas y los modos cómo el yo femenino se proyecta en y redefine los espacios en los que se despliega.

En este estudio usaré el concepto "desposesión" para referirme a las diversas lógicas de sujeción que limitan la capacidad de autodeterminación de los sujetos femeninos. En sus diálogos sobre los alcances políticos de esta categoría, Judith Butler y Athena Athanasiou entienden la desposesión, por una parte, como un conjunto de condiciones que impiden a las y los sujetos ejercer su total voluntad sobre su individualidad puesto que, como seres sociales, responden a un tejido de interacciones afectivas y culturales con otras y otros. Por otro lado, la desposesión, señalarán las autoras, refiere a una serie de discursos restrictivos y políticas de control que en sociedades jerárquicas despoja a las y los sujetos de toda autoridad sobre sí y su mundo (Athanasiou 15-17). De tal forma que sus cuerpos, sus identidades, sus historias, territorios y posesiones materiales serán determinados por un sistema social, político y cultural sobre el que no tienen posibilidad de influir. Si bien la desposesión puede operar a partir de la represión e imposición forzosa, también puede desplegarse de manera hegemónica. Es decir, instalando un horizonte discursivo y simbólico en el que las y los sujetos creen identificar sus auténticos deseos e intereses, quedando, sin embargo, atrapados en modelos identitarios y sociales que les son ajenos y que obstaculizan toda posibilidad real de autodeterminación:

En este sentido, la desposesión es algo relacionado con el concepto marxista de la alienación, el cual opera en dos niveles: los sujetos trabajadores son desprovistos de la habilidad de tener o poseer algún tipo de control sobre sus vidas, pero al mismo tiempo son negados de la conciencia de este yugo al ser interpelados como sujetos de una libertad inalienable (Athanasiou 21). 
De este modo, el concepto de desposesión permite entender cómo las formas de privación que afectan a las mujeres en sociedades patriarcales $-\mathrm{y}$ las determinan a roles asistenciales y pautas de comportamiento que impiden su autonomía- son impuestas pero, asimismo, incorporadas y asumidas por los sujetos femeninos como condiciones naturales de existencia, dificultando con ello aún más la toma de conciencia del estado de sujeción. En las primeras líneas de La brecha el carácter hegemónico y, por tanto, indiscutible de las normas del sistema sexo-género se evidencia con claridad lapidaria:

Me casé como todo el mundo se casa. Ese mundo de las horas de almuerzo, del dedo en alto, guardián de la castidad de las niñas. Antes de los veinticinco años debía adquirir un hombre -sine qua non- que velara por mí, me vistiera, fuera ambicioso y del que se esperara, al cabo de cierto tiempo, una buena posición: la mejor posible (Valdivieso 13).

De igual manera, la categoría de desposesión posibilita leer el proceso de sujeción de la mujer en clave no solo cultural y política, sino también económica y material. En tal sentido, es importante destacar que La brecha es una de las primeras narraciones chilenas en abordar la subordinación femenina considerando su situación de dependencia económica.

\section{LA REDEFINICIÓN DE LA “OTRA”, MÁS ALLÁ DEL BINARISMO}

Al igual que la protagonista de La última niebla, la de La brecha no tiene nombre. Lucía Guerra-Cunningham señala que este recurso en la novela de Mercedes Valdivieso permite universalizar la experiencia del personaje: "la confesión íntima se transforma en un testimonio colectivo con un claro propósito social" (6). En otras palabras, más que definir una individualidad femenina, dueña de una subjetividad y una historia única, Valdivieso está por sobre todo interesada en ofrecer un tipo femenino en el que muchas pueden espejear su propia subordinación y así visibilizar las condiciones de exclusión y sometimiento que las afectan. Sin desconocer la pertinencia de esta lectura, a mi modo de ver esta ausencia de un nombre propio es parte de la indeterminación a la que está confinada la mujer, un "no ser" (Valdivieso 63) que la misma protagonista advierte cuando está sumergida en la niebla 
en medio del desmayo. La ausencia de un nombre indica, así, otra ausencia: la de un yo con capacidad de agencia sobre un proyecto vital propio.

En La última niebla ese "no ser" se materializa en la imposición del marido de la protagonista a que esta reproduzca el modelo de la primera esposa. Todo rasgo que evidencie una identidad particular y que la distancie de la figura de la primera mujer es inmediatamente eliminado. El cabello rojo y largo de la heroína, que la distingue del resto de las mujeres, será atado y peinado para así amoldar su cuerpo al diseño autorizado de la mujer ideal. En La brecha, la protagonista también experimenta esta política de anulación de su diferencia. Desde los primeros pasajes de la novela, la narradora reconoce que su vida debe ser como todas las otras vidas de mujeres. Se casa porque todas se casan, porque ella ha sido inscrita en un paisaje femenino al que debe ajustarse. Su responsabilidad es la de seguir un guion preestablecido: el noviazgo autorizado por los padres, el esperado matrimonio con alguien de su misma posición social, la maternidad y una vida dedicada al hogar y a los suyos. En definitiva, madurar y envejecer primero bajo la tutela de los padres y, luego, la del marido. Sin embargo, la protagonista decidirá apartarse de este guion asignado a su género sexual, provocando un quiebre profundo con su entorno familiar y la desazón del marido: “-¿Qué te imaginas? ¡Despreciando siempre lo que yo estimo, viviendo ciega y sorda a lo que ha sido mi vida, saltando sobre principios que cualquier mujer respeta, la religión, por ejemplo, limitándose a un hijo!" (Valdivieso 41).

Esta decisión de distanciarse de un relato establecido deja a la protagonista a la deriva en cuanto a imágenes y narrativas sobre las cuales construir su individualidad y su proyecto personal. En este plano, la presencia de su amiga Marta será fundamental para superar la desposesión e iniciar un camino de reinvención de su identidad. Marta es definida por la protagonista como una mujer de carácter, franca, que enviudó tres años antes y que goza de un buen pasar económico. Marta ha tomado la decisión de no volver a casarse, porque para ella las únicas razones que explican la necesidad de contraer matrimonio es acceder a una holgada situación económica o vivir una gran pasión (Valdivieso 59-60). Marta señala que, respecto a lo primero, tiene recursos suficientes para vivir sin sobresaltos y no requerir el apoyo de un varón, $\mathrm{y}$, en cuanto a las pasiones, entiende que ellas no dependen del estado civil. Marta es una mujer liberal, no solo es dueña de un nombre propio, sino también de su vida. Encarna el antimodelo a la femineidad patriarcal y por ello es percibida como una amenaza por el marido de la protagonista (Valdivieso 60). 
En las narrativas de mujeres de la primera mitad del siglo XX es frecuente encontrar personajes femeninos, cercanos a las protagonistas, que no se ajustan del todo a las normas del sistema sexo-género o abiertamente desobedecen el mandato patriarcal. La prima que vive un amorío adúltero en La última niebla; la hermana que decide huir de la casa de la tía e iniciar una carrera de actriz de teatro en "La casa iluminada" (1944), de la chilena Marta Brunet; Mercedes Galindo, la salonnière culta con una intensa vida social que genera aversión entre las mujeres conservadoras de Caracas en Ifigenia (1924), de la venezolana Teresa de la Parra; Dora, la estudiante despreocupada y libre en Jirón de mundo (1919), de la mexicana María Enriqueta son algunos ejemplos del universo amplio y variado de perfiles femeninos que desafían la pasividad obediente y sacrificial del "ángel del hogar". Sin embargo, a diferencia de como ocurre en La brecha, estos personajes femeninos no se disponen catalizando una voluntad emancipadora en sus cercanas y apoyando un proceso de transformación individual en sus pares de género sexual.

En su estudio sobre la literatura de autoras inglesas y norteamericanas del siglo XIX, las críticas Sandra Gilbert y Susan Gubar profundizan en aquellos personajes femeninos que, de manera disruptiva, encarnan valores contrarios al mandato patriarcal:

Hasta las escritoras de apariencia más conservadoras y decorosas crean una y otra vez personajes ferozmente independientes que tratan de destruir todas las estructuras patriarcales que tanto sus autoras como las heroínas sumisas de éstas parecen aceptar como inevitables. Por supuesto, al proyectar sus impulsos rebeldes no en sus heroínas, sino en mujeres locas o monstruosas (que son castigadas como les corresponde en el curso de la novela o poema), las autoras dramatizan su propia división, su deseo tanto de aceptar las censuras de la sociedad patriarcal como de rechazarlas (92).

Si bien el análisis de Gilbert y Gubar se centra en un corpus distinto al que revisamos acá, sus propuestas son pertinentes para indagar figuras similares en narrativas de mujeres de otros contextos culturales y épocas. Para las investigadoras, estas imágenes de mujeres transgresoras a las normas patriarcales pueden ser leídas como proyecciones de las autoras, de su "ansiedad de autoría". O, en otras palabras, de la necesidad de las escritoras de problematizar modelos patriarcales de género sexual que las han situado fuera de los espacios políticos y culturales y, por tanto, le han negado su 
derecho a contribuir en sus esferas artísticas y literarias y a ser reconocidas en cuanto creadoras. Sin embargo, esa "otra" caracterizada como una imagen monstruosa que trastorna y desajusta en su recorrido extravagante el mundo de la protagonista, reproduce la estigmatización patriarcal sobre aquellas que osan desobedecer las normas de género sexual. En tal sentido, la imagen de la "otra" en la escritura de mujeres está signada por la ambivalencia: expresa metafóricamente la necesidad de discutir y desautorizar el mandato patriarcal $\mathrm{y}$, a la vez, replica los marcos simbólicos de dicho mandato al reducir la diferencia a un elemento disociador y destructivo, que no solo amenaza el orden sexo-género sino también a la propia protagonista.

En La brecha, Mercedes Valdivieso se distancia de este esquema dicotómico de representación femenina, que instala, por un lado, a una protagonista que cumple con las normas de género sexual y, por otro, a su antítesis, cuya presencia se limita a sabotear el sistema sexo-género y desestabilizar las creencias de la protagonista pero sin abrir posibilidades reales de emancipación en ella. En tal sentido, Marta no solo demuestra preocupación por su amiga: también la conoce, conoce su historia y su carácter. No irrumpe desequilibrando el mundo convencional de la protagonista, porque ha estado desde siempre a su lado, como parte de su círculo afectivo. Si en la mayoría de las obras latinoamericanas mencionadas, la "otra" suele constituirse como una presencia arrolladora, cuya entrada en la historia perturba el tiempo cíclico e invariable de la protagonista, en La brecha, Marta se sitúa como un modelo femenino poco convencional, pero en ningún caso extraño, lo que facilita que la protagonista se pueda identificar con ella. En este sentido, la presencia de Marta aparece como una posibilidad real de cambio y no como una anomalía.

Mercedes Valdivieso al apartarse de la definición tradicional de la "otra" de la literatura de mujeres, supera la estigmatización de este tipo de personajes femeninos que responde a los códigos morales de una sociedad patriarcal. Es por ello que el personaje de Valdivieso está lejos del destino acostumbrado de esas "otras" que pueblan las ficciones. Marta no será condenada a un final aciago, al aislamiento o a quedar confinada a un rincón del relato, desterrada a un cronotopo distante de la historia de la protagonista. Su vida, sin la tutela y el acompañamiento masculino, no está signada por la soledad sufriente. Por el contrario, se desenvuelve a lo largo de la novela como una mujer autónoma, con proyectos, dueña de una vida social activa y siempre cercana a su amiga.

Es importante mencionar que este no es el primer intento, en narrativas de mujeres latinoamericanas, por superar los modelos de representación de la otredad femenina asociados a lo extraño, figuras raras que escapan totalmente 
al mundo convencional de las protagonistas. En este plano se sitúa Dora, la amiga de Teresa del Río, la esforzada institutriz protagonista de Jirón de mundo de María Enriqueta. Dora es una estudiante independiente, vivaz, con sentido del humor, confidente y consejera de Teresa y que, a diferencia de esta última, se desenvuelve con total espontaneidad en la esfera pública. Nada en la descripción de Dora recuerda a esa individualidad femenina disociadora que trastorna la vida de la protagonista y cuyo rol se reduce a provocarla. Por el contrario, Dora termina siendo un remanso de tranquilidad para una doliente Teresa. En la novela, Dora interrumpe brevemente la dicotomía ángel del hogar/mala mujer que se encarna en los personajes Teresa del Río y Laura Santiesteban -la hija caprichosa de la casa en donde Teresa ejerce como institutriz-, respectivamente. Sin embargo, su presencia es tan fugaz que no se traduce en una superación definitiva de este esquema binario. Aunque con un mayor protagonismo que esta última, el personaje de Nina, la estudiante universitaria de La mampara (1946) de Marta Brunet, que está constantemente desafiando los parámetros convencionales de femineidad, también ocupa un lugar muy secundario en la historia. Confinada a un par de pasajes de la novela, Nina aparece como una muchacha inteligente, defensora de su independencia y crítica de la superficialidad burguesa de su familia. Si bien Nina es disruptiva en su entorno, su presencia crítica no se describe como una suerte de anomalía. Por el contrario, en muchos sentidos sus ideas, claramente expuestas, proyectan la visión autoral que organiza ideológicamente el texto. En la novela Luz y sombra (1919) de la puertorriqueña Ana Roqué, la dicotomía representacional de lo femenino es desarticulada al instalar en un mismo plano de relevancia las historias de dos amigas que toman decisiones distintas en su vida afectiva, lo que les acarreará consecuencias también diversas. Ninguna de las dos protagonistas se ajusta del todo a las características de ángel del hogar/mala mujer. Si bien Matilde parece responder al modelo de una joven convencional, que busca realizarse en un matrimonio feliz, también discute la desposesión de la que es víctima y se rebela contra las decisiones paternas. Por otro lado, su amiga Julia, que al inicio se define como una mujer con autodeterminación, algo superficial y ambiciosa, con el correr de la historia se verá envuelta en contradicciones, padeciendo un matrimonio infeliz. En la novela, sin embargo, no hay ninguna imagen que represente a una mujer dueña de sí y con posibilidades reales de lograr exitosamente una vida fuera de las estructuras que dispone el sistema sexo-género. En efecto, ambas amigas solo proyectan su futuro dentro del marco 
del matrimonio ${ }^{1}$. Estos personajes femeninos, como tantos otros, demuestran los esfuerzos creativos e ideológicos de las autoras por superar los moldes de una otredad femenina que no puede sino reproducir estereotipos patriarcales. Sin embargo, estas representaciones menos exageradas de la desobediencia femenina y, por lo mismo, más complejas, terminan siendo personajes menores en las tramas y no determinantes en el proceso de problematizar a fondo la desposesión de ellas y de sus pares de género sexual.

Es particularmente interesante observar que, en La brecha, Mercedes Valdivieso pone en voz de Marta la crítica a este modelo binario del ángel del hogar/mala mujer: "pero la vanidad masculina es ciega: las mujeres se entregan por amor o se prostituyen por dinero. Casos extremos. ¿Y el término medio? ¿Una mezcla de amor y prostitución, de prostitución y amor?” (58). La reflexión de Marta, no exenta de una dosis de sarcasmo, deja en evidencia cómo Valdivieso concibe a este personaje fuera esa lógica de opuestos femeninos.

\section{LOS ESPACIOS DEL YO}

Uno de los rasgos más significativos de La última niebla de María Luisa Bombal es el carácter homologador que tiene la niebla en los espacios en los que se disemina. La bruma envuelve el campo y la ciudad desdibujando los objetos, los elementos naturales, los diversos rincones y ámbitos en los que se desplaza la protagonista. La niebla hace del afuera un no lugar, prácticamente indefinible e inexistente. El carácter ambiguo e irreal que tiene el exterior para la protagonista contrasta con su vida en el espacio privado, presa de una rutina familiar agobiante y marcada por las certezas lapidarias del marido.

Ninguno de estos espacios, ni el afuera difuminado por la niebla, ni el adentro controlado por lógicas familiares, realmente le pertenecen. La protagonista carece de un cuarto propio o de un lugar en la casa en la que pueda definir y administrar a voluntad. Tampoco puede ejercer control en los ámbitos externos. Salvo el momento en el que se sumerge en la fuente y disfruta de su cuerpo libremente, en contacto con el flujo del agua, el resto

\footnotetext{
En relación con los modos en cómo Ana Roqué dialogó con una determinada tradición simbólica de mujeres, recomiendo revisar el artículo de Natalia Cisterna y Lucía Stecher. "Diálogos textuales y personales: Carmela Eulate Sanjurjo, Ana Roqué de Duprey y el feminismo puertorriqueño a principios del siglo XX". Anclajes XXI. 3, 2017, pp. 25-41.
} 
de su experiencia en ese mundo externo está marcada por fuerzas que le son ajenas y que escapan a su comprensión. La desposesión de un espacio propio es parte importante de la sujeción que sufren las protagonistas en las narrativas de mujeres. En Ifigenia, el cuarto heredado de la tía que recibe María Eugenia Alonso al llegar a Caracas, decorado de acuerdo a lo que se consideraba apropiado de una mujer virtuosa y la prohibición de ocupar el resto de la casa para leer, tocar el piano o cualquier actividad personal que no corresponda a la rutina doméstica, es parte de la violenta y efectiva mecánica de anulación de la individualidad que sufrirá la adolescente. Asimismo, su derecho de ocupar el afuera se ve restringido por la autoridad familiar, cuya cabeza es el tío. La obligación de Nina de tener que compartir el cuarto con su hermana en La mampara, un cuarto despersonalizado y decorado por la madre con costosos muebles acordes al estatus económico de la familia, tiene también como fin situar a la estudiante dentro de los marcos de clase social y de femineidad aceptados por el grupo. En Jirón de mundo, en tanto, Teresa del Río carece totalmente de un espacio propio. Vive para satisfacer las demandas de otras y otros en el mundo conventual y en la casa de los Santiesteban. Sus obligaciones como institutriz le impedirán, incluso, aprovechar para sí ese tiempo personal fuera de las horas de trabajo, en el cuarto asignado dentro de la casona. La calle, por otro lado, la aterra: la marea de personas que circulan en ella, el azar y la inestabilidad de la urbe se le presentan como una amenaza y no como una oportunidad para alcanzar cierta independencia en el anonimato citadino.

La posibilidad de reconocerse en un lugar y de administrarlo libremente es uno de los anhelos más frecuentes en las protagonistas de narrativas de autoras latinoamericanas. En Ifigenia, María Eugenia Alonso buscará desesperadamente rincones en la casa de la abuela que escapen a la vigilancia. Nina, en La mampara, discutirá la imposición de la madre de compartir un cuarto con la hermana y exigirá su derecho a tener uno propio, en donde poder estudiar y recibir a sus amistades. En Jirón de mundo, la institutriz, aunque poseedora de un carácter sumiso y obediente de las normas de género, muy distintas a las otras protagonistas, se dejará arrastrar por momentos por su imaginación para desplazarse a otros lugares y compañías. El sueño termina siendo, para muchas de estas protagonistas, el lugar por excelencia en el que podrán elaborar con más libertad sus deseos, como es el caso de los personajes femeninos centrales de La última niebla de María Luisa Bombal, Ifigenia de Teresa de la Parra y la protagonista de "Soledad de la sangre" (1943) de Marta 
Brunet. Al respecto, Lucía Guerra-Cunningham, refiriéndose a las heroínas de las narrativas de autoras chilenas de ese periodo, señalará:

Como ciudadana de segunda categoría condenada a las cuatro paredes de una casa, como ser alienado en la rutina y monotonía del hogar, su acto de subversión no es más que una incursión en lo amoroso, una sublimación en su contacto con la Naturaleza de la actividad erótica reprimida por el código moral, intentos que deben claudicar ante la fuerza poderosa de las convenciones sociales (6).

Al igual que en las narraciones latinoamericanas previas, en La brecha la sujeción femenina cristaliza en las dificultades que enfrenta la sujeto para configurar su yo en esferas privadas y públicas sin la tutela o la vigilancia de quienes representan la autoridad patriarcal. Al respecto, en su historia se pueden distinguir cuatro etapas claves en el proceso de desposesión que sufre y sus intentos por recuperar un mayor control de sí y sus espacios. La primera etapa corresponde a su niñez, que ocupará algunos breves pasajes en sus recuerdos. La casa familiar, en la que habita por aquel entonces, tendrá como figura central al padre, el que, lejos de coartar su libertad a los parámetros del sistema sexo-género, permite a su hija ejercer su voluntad con relativa independencia a los parámetros de género. En aquellos días, el matrimonio, la maternidad y una vida dedicada a labores hogareñas no son parte del proyecto vital que el padre esboza para su hija: "-Cuando crezca, nos iremos a Europa solos; no existirá mozalbete capaz de usted -me decía él" (Valdivieso 13).

Salir de casa a encontrarse con amigos, usar juguetes masculinos, disponer de su tiempo fuera y dentro del hogar son cosas que quedarán abruptamente en el pasado con la muerte del padre. Al respecto, Andrea Kottow y Ana Traverso plantearán que esta imagen de la muerte del progenitor, asociada al fin de una era de plenitud, está presente en una serie de narrativas de autoras chilenas. La "expulsión del paraíso", señalan las investigadoras, traerá consigo la reclusión del yo femenino a las fronteras de su subjetividad, dando inicio con ello a la necesidad de escribir (63).

Con la muerte del padre, se iniciará una segunda etapa en la vida de la protagonista en la que las pautas de género sexual se impondrán sobre ella a través del férreo mandato de la abuela materna: “-Eres mujer y aprenderás a zurcir y a estar quieta; nadie querrá que a los diez días de casada te devuelvan por inútil" (Valdivieso 14). La anciana corregirá el desvío al sistema sexo- 
género en el que había incurrido la niña con la venia del padre, permitiendo con ello que la protagonista se amolde a las reglas de género que rigen el destino de todas. Ese periodo que va desde la muerte del padre hasta el matrimonio se desplegará como una larga espera con esporádicas muestras de resistencia en la época escolar. Este tiempo de antesala se desarrollará en espacios determinados de acuerdo a su género sexual y clase social: la casa de la madre, la escuela privada de niñas y la iglesia. La joven verá, así, limitados sus movimientos a los mapas autorizados por la progenitora.

El tercer momento corresponde a su matrimonio. La protagonista pasa de estar bajo la tutela de la madre a la del marido. El derecho de propiedad que ejerce permanentemente Gastón, el esposo, sobre su cuerpo, tiempo y espacios es total. Como un vencedor la exhibe, la arrastra a lugares públicos que son importantes para él y a aquellos espacios personales que tienen sentido en su historia afectiva, como la casa de su madre. Toda decisión que la protagonista tome, como la de no tener más hijos o establecer vínculos que no cuenten con la autorización de Gastón, será motivo de discusión y reproche por parte de este. Por ejemplo, la relación estrecha entre ella y su hijo, de la que el padre queda completamente fuera, despertará los celos del esposo y profundizará la crisis de la pareja. En esa etapa de su existencia, el proceso de desposesión, iniciado de modo sistemático en su infancia con la presencia autoritaria de la abuela, se consolida. La posibilidad de desplegar su individualidad en el mundo se cierra. El cónyuge determinará los espacios en los que interactúa la protagonista, como también la forma en la que participa en ellos: "Dejé pertenecerme por fuera y me amurallé por dentro" (Valdivieso 20), señalará la mujer, recordando aquellos años de matrimonio. A pesar del control que se ejerce sobre ella, encontrará formas para eludir la vigilancia marital. La relación paralela que tendrá con otro hombre le permite no solo establecer un tipo de vínculo sin las presiones y chantajes que sufre en el seno del matrimonio, sino también contar con un lugar de encuentros clandestinos en el que podrá sentirse a gusto; un espacio que ella manejará y ocupará libremente. El departamento oculto termina siendo un espacio de desahogo y de fuga que, sin embargo, no altera en nada su condición de subordinación y responde más bien a ese mismo estado de amurallamiento al que la arrincona el sistema patriarcal. En efecto, la imposibilidad de ser dueña de sí y de contar con esferas propias de desarrollo individual solo le deja dos alternativas: obedecer o burlar secretamente el mandato patriarcal, pero sin desautorizarlo públicamente. El encuentro secreto de la protagonista de $L a$ brecha en el departamento nos remite, de alguna manera, al furtivo romance 
del personaje de María Luisa Bombal en la casa en la ciudad. Sin embargo, la distancia entre ambas novelas es evidente. Mientras la relación adúltera de la protagonista de Bombal se despliega en un estado de ensoñación y alcanza tal grado de ambigüedad que la hace incluso dudar de su existencia, en $L a$ brecha el romance por fuera del matrimonio no se pone en duda, llegando a adquirir un carácter rutinario con tiempos de encuentros determinados.

La última etapa del proceso de desposesión y de lucha por ejercer su voluntad se iniciará con la decisión de la protagonista de separarse y comenzar una nueva vida junto a su hijo. Es en ese momento cuando para ella el mundo se ensancha (Valdivieso 61), sobre todo gracias a la feliz intervención de su amiga Marta. Gran parte de la narración se centra, precisamente, en describir esta etapa de emancipación como un camino complejo y repleto de dificultades. No es común encontrar en las narraciones de escritoras latinoamericanas de las primeras décadas del siglo XX una representación del tránsito de las protagonistas hacia un yo femenino empoderado, exponiendo las dificultades, desafíos y dudas que debe enfrentar. En La última niebla o en Jirón de mundo, por ejemplo, la autodeterminación ni siquiera es vislumbrada por sus protagonistas como una posibilidad. Ambas están sumergidas en las contradicciones entre dar curso a sus deseos (que apenas logran distinguir y procesar intelectualmente) y el deber que les impone el sistema sexo-género. En Ifigenia, la etapa de descubrimiento y exploración de su subjetividad corresponde al pasado parisino de María Eugenia Alonso, caracterizado por cierta autonomía económica y el relajo de la vigilancia familiar, que es interrumpida de manera repentina por su obligado regreso a Caracas. La voluntad de autodeterminación cubrirá un tiempo breve que ella rememorará con nostalgia en el encierro venezolano. En La mampara, en tanto, Nina se presenta con una identidad y opiniones ya formadas, omitiéndose el recorrido emocional e intelectual que le permitió asumir esa posición crítica $\mathrm{y}$, en definitiva, tomar distancia del arribismo familiar y los modelos convencionales de género sexual.

En La brecha, en cambio, asistimos a un viaje de autodefinición que nos permite observar la emancipación femenina como un proceso difícil y marcado por distintos retos y barreras que sortear. En este sentido, en la novela, la independencia de la mujer no se alcanza con la finalización del matrimonio, el que constituye una pieza más dentro de las dinámicas de desposesión que afectan a una mujer. Por ello, La brecha no termina con la decisión de la protagonista de abandonar al marido, más bien dicha decisión es el inicio de un itinerario largo, en el que la tutela masculina se revela también en términos económicos. En este sentido, La brecha es una de las primeras novelas en la 
que, de manera explícita, la lucha por la autodeterminación femenina está asociada a la superación de las precarias condiciones materiales a las que están condenadas las mujeres. Tener recursos suficientes para alquilar un departamento, garantizar su subsistencia y la de su hijo y gozar de cierto bienestar económico son preocupaciones constantes para la protagonista una vez que deja la casa del marido. La desposesión se vivencia por ella no solo como una serie de impedimentos sociales y culturales que la obligan a roles asistenciales dentro del matrimonio, sino también como la dependencia material al varón. En la novela, en definitiva, se hace evidente que la sujeción de la mujer responde a condiciones estructurales sociales, culturales y económicas, que no se resuelven solo a partir de una decisión personal de finalizar el vínculo matrimonial o abandonar una relación abusiva. Es por ello que la autodeterminación femenina tiene en la novela un carácter gradual y permanente: "Miro hacia delante y comprendo que falta mucho por romper, porque falta mucho pasado que abrir" (Valdivieso 140-141), dirá la protagonista hacia el final de su relato.

En sus palabras, la emancipación es un proceso de luchas diarias que la obligan también a examinar las políticas de desposesión de las que ha sido víctima en el pasado y que todavía repercuten en su presente. La narración estructurada como un ejercicio de memoria, que revisa los distintos episodios de dependencia a lo largo de su vida, cumple esta función de "abrir el pasado", explorando críticamente aquellas vivencias en las que los mecanismos de control se impusieron sobre su voluntad. En este marco, no dejan de ser paradojales las palabras del marido, en medio de una discusión: "no olvides lo que te enseñaron de niña" (Valdivieso 65), dirá desesperado al ver derrumbarse su matrimonio. La exigencia de no olvidar el mandato patriarcal terminará siendo asumida por la protagonista con un sentido totalmente distinto: efectivamente no olvidará, pero no para obedecer sino para entender y desarticular dicho mandato.

La decisión de separarse y de agenciar su vida lleva a la protagonista a configurar sus propios desplazamientos y espacios. El mundo se le amplía, pero también se cartografía desde una perspectiva no tutelada: "empezaba a ensancharse la retina como si me quitaran vendajes de mucho tiempo sobre los párpados" (Valdivieso 80). Su experiencia en la calle, paseando y observando en distintas horas la vida urbana, harán de ella una flâneuse atenta que identifica en la ciudad diferencias, simetrías y contradicciones. No pasará por alto a las adolescentes con pantalones ajustados y cabellos sueltos, que despreocupadas se bajan de las motos de los amigos. En contraste con su juventud limitada 
a la iglesia, la escuela y la casa, la imagen de las muchachas será la postal de una nueva forma de definir la femineidad de las jóvenes generaciones de mujeres. Y así como la esfera urbana le ofrece los signos de una identidad emancipada, abriéndole un futuro prometedor, también le muestra las zonas más opacas de un desarrollo económico y social desigual. Las fachadas de las mansiones con autos lujosos estacionados afuera, en contraste con la modesta vida en el centro de la ciudad serán objetos de su observación crítica; tampoco le serán indiferentes las masas de trabajadores agrupadas esperando el autobús, sometidas a un ritmo laboral deshumanizador: “¡Cómo es posible que soporten tanto!" (Valdivieso 83), dirá al contemplarlas.

Así, la protagonista de La brecha no solo toma conciencia de las características de su propia subordinación, sino que también dimensiona y discute el abandono y los abusos a los que están sometidos otros menos favorecidos económicamente que ella. "Ya no puedo renunciar a pensar" (Valdivieso 66), le dirá a su marido en un momento. Esta confesión constituye la mejor descripción del particular proceso de autodefinición que experimenta la protagonista. Interrogar permanentemente el sistema sexo-género y las lógicas de subordinación patriarcal que la formaron conlleva interrogar las estructuras sociales de exclusión que afectan, en distintos grados, a hombres y mujeres. En este punto concuerdo con las reflexiones de Lucía GuerraCunningham, quien plantea que la novela de Mercedes Valdivieso se aparta del feminismo liberal, cuyas demandas se limitan a "conquistas parciales" en el plano político y cultural. La brecha, señala la investigadora, se inscribe en un feminismo de izquierda que busca modificar de manera radical el modelo capitalista que da lugar a la explotación de mujeres y hombres, para "crear una sociedad basada en la igualdad y la verdadera libertad" (9).

Es importante señalar que no son frecuentes las representaciones de trabajadoras en espacios laborales urbanos en narrativas de autoras previas a La brecha. Son contados los relatos de escritoras que presenten a mujeres ejerciendo funciones en colegios, talleres e industrias, oficinas o editoriales ${ }^{2}$. Uno de ellos es la novela La mampara de Marta Brunet, en la que una joven, Ignacia Teresa, se ve obligada a salir de casa para desempeñarse como

\footnotetext{
Para ahondar en las escasas imágenes de mujeres en labores culturales y creativas, en las narrativas de escritoras, sugiero revisar mi artículo "Ceremonias letradas: representaciones del campo cultural en la narrativa de autoras latinoamericanas y caribeñas de la primera mitad del siglo XX”. Taller de letras 59, 2016, 151-167.
} 
secretaria en una oficina. La escena en la que la protagonista de La brecha inicia su primer día de trabajo recuerda sutilmente la atmósfera laboral que envolvía al personaje brunetiano. Al igual que en esta última novela, las tareas de la protagonista de Valdivieso se desarrollan en un ambiente mecánico y despersonalizado. Las relaciones con los jefes son frías y se limitan a órdenes precisas. Las empleadas y empleados apenas se conocen y tienen escasos espacios de interacción, por lo que el establecimiento de vínculos y la identificación de intereses compartidos que den lugar a un sentido de comunidad son prácticamente inexistentes. Una fugaz conversación con otra empleada le muestra el verdadero sentido que tiene para las mujeres que la rodean el trabajo:

-Te ves muy interesada en lo que haces.

Sus ojos se llenaron de asombro.

[...]

-Me desagrada del todo, pero tengo que vivir, ayudar en mi casa y vestirme. Al salir del colegio, ser secretaria era lo más corto para ganarse la vida. Ahora lo hago mecánicamente. ¡Pero lo que me costó! (Valdivieso 128).

Tal como en La mampara, en La brecha el trabajo femenino es deshumanizante y brinda escasas posibilidades para el progreso de la mujer. Mercedes Valdivieso vuelve, así, sobre ideas centrales que estaban en las cavilaciones de Marta Brunet en la década del cuarenta, pero que ya eran parte de los debates y reflexiones de las feministas desde los primeros años del siglo $\mathrm{XX}^{3}$. De este modo, La brecha se sitúa en un recorrido de imágenes $\mathrm{y}$ discusiones sobre el trabajo femenino presentes en la literatura y en escritos políticos de mujeres.

El diálogo intertextual con La mampara no se limita a la representación de la oficina y el trabajo femenino. La imagen de la protagonista de La brecha en una fuente de soda, en medio de un break laboral, recuerda la ida a un

\footnotetext{
El Movimiento Pro-Emancipación de las Mujeres de Chile (MEMCH), en 1935, planteaba en su programa político la igualdad salarial y la necesidad de mejorar la calidad de vida y las condiciones laborales de obreras y empleadas. Al respecto, sugiero ver el boletín oficial del MEMCH, La mujer nueva, del 8 de noviembre de 1935. Los números digitalizados de este periódico se pueden encontrar en el sitio Memoria Chilena: www.memoriachilena. gob.cl
} 
lugar similar de Ignacia Teresa en la novela de Brunet. Sin embargo, mientras el personaje de La mampara se autocompadece en el negocio de comidas y anhela tener la compañía de un varón en la cual refugiarse, la protagonista de La brecha disfruta plenamente esa cápsula de tiempo propio en la soledad del establecimiento: "Aquel sitio era el tiempo que me imponía cuando salía a la calle a respirar y pensar" (Valdivieso 129).

Al igual que otras narrativas de autoras latinoamericanas previas, la novela de Mercedes Valdivieso asigna a la soledad un carácter emancipador que permite a las protagonistas redescubrirse, explorar en su memoria los momentos determinantes en sus vidas, elaborar proyectos y sumergirse en ensoñaciones. Asimismo, la soledad las libera, aunque sea brevemente, de las obligaciones sociales y los marcos valóricos que rigen el sistema sexogénero. En este plano, la protagonista de La brecha no se aleja de otras representaciones del tiempo personal femenino. Sin embargo, la soledad adquiere en esta novela un sentido mucho más amplio que en obras como La mampara, Ifigenia, La última niebla, Jirón de mundo o "Soledad de la sangre", por nombrar algunos relatos ya mencionados. En efecto, en la novela de Valdivieso la soledad no se limita a constituirse como un tiempo de aislamiento, de desconexión total con el afuera. Mientras en las otras narraciones los deseos y sueños que tienen lugar en la esfera íntima no encuentran espacios de expresión en el exterior y solo pueden manifestarse en recónditos territorios propios, en La brecha las ideas y anhelos presentes en el cronotopo personal se articularán con tomas de posición y decisiones que se asumen en la vida pública. La división entre la vida secreta (marcada por la soledad del cuarto) y la vida pública se desdibujará. La escena en la que la protagonista deambula por su departamento, descubriendo rincones y revisando sus recuerdos amontonados en distintas partes es particularmente reveladora. En ella, la protagonista encontrará la fotografía de su matrimonio, en la que aparece vestida con su traje de boda, con la mantilla heredada por las mujeres de su familia, símbolo de un destino común de sometimiento femenino (Valdivieso 77). La protagonista lanzará con energía la foto adentro de un clóset, desechando con ello un modelo de femineidad que le ha sido impuesto. El gesto privado tendrá una manifestación en la esfera pública al romper con su marido e iniciar una vida sin su tutela. La fotografía, sin embargo, no se quebrará como lo habría deseado, pero quedará arrinconada en un lugar oscuro como imagen de un proceso de emancipación femenina que no depende de un solo gesto o una conquista parcial de derechos, sino de una suma de decisiones y luchas continuas. 


\section{A MODO DE CONCLUSIÓN}

Es posible reconocer la novela La brecha en el marco de una tradición de representaciones femeninas elaboradas por autoras latinoamericanas que, durante la primera mitad del siglo XX, configuraron imágenes del sujeto femenino y su mundo que desafiaron o interrogaron los paradigmas del sistema sexo-género. En esta genealogía representacional e ideológica, la novela de Mercedes Valdivieso se sitúa dando continuidad a una serie de preocupaciones e ideas sobre el lugar de la mujer en una sociedad patriarcal pero, al mismo tiempo, renovando, desde una perspectiva feminista, construcciones de lo femenino que estaban presentes en las narrativas de mujeres que le antecedieron. Al respecto, la novela invita a reinventar los modelos en los que las mujeres nos reconocemos y leer desde una perspectiva histórica y estructural la desposesión de la que somos víctimas. Para ello, nos despliega una historia en la que se supera el binarismo ángel del hogar/mala mujer, evitando exhibir la emancipación femenina como una simple performance disruptiva y descontextualizada, para representarla como un proceso de luchas constantes y de ocupación y resignificación de nuevos y antiguos espacios.

\section{BIBLIOGRAFÍA}

Athanasiou, Athena y Judith Butler. Desposesión: lo performativo en lo político.

Buenos Aires, Eterna Cadencia, 2020.

Bombal, María Luisa. "La última niebla". Obras completas. Santiago de Chile, Andrés Bello, 1996.

Brunet, Marta. La mampara. Obra narrativa. Novelas. Tomo I. Santiago de Chile, Ediciones Universidad Alberto Hurtado, 2014.

"La casa iluminada". Obra narrativa. Cuentos. Tomo II. Santiago de Chile, Ediciones Universidad Alberto Hurtado, 2017.

"Soledad de la sangre". Obra narrativa. Cuentos. Tomo II. Santiago de Chile, Ediciones Universidad Alberto Hurtado, 2017.

De la Parra, Teresa. Ifigenia. Diario de una señorita que escribió porque se fastidiaba. Lima, Ediciones Antártica, 1960.

EnRiQueta, María. Jirón de mundo. Madrid, Editorial América, 1919.

Guerra Cunningham, Lucía. "Feminismo y subversión en La brecha de Mercedes Valdivieso". Literatura chilena. Creación y crítica 21, 1982, pp. 5-9. 
Gilbert, Sandra y Susan Gubar. La loca del desván. La escritora y la imaginación literaria del siglo XIX. Madrid, Ediciones Cátedra, 1998.

Kottow, Andrea y Ana Traverso. Narrativas escritas por mujeres en Chile (19201970). Santiago de Chile, Overol, 2020.

Roqué, Ana. Luz y sombra. San Juan, Editorial de la Universidad de Puerto Rico, 1991. Valdivieso, Mercedes. La brecha. Santiago de Chile, Zig-Zag, 1961. 